\title{
Business Identity as a Determinant of CEO Compensation
}

\author{
Jae H. Song \\ Saint Cloud State University \\ Susantha Herath \\ Gannon University \\ Changsoo Sohn \\ Saint Cloud State University
}

\begin{abstract}
Using the Dow Jones Industrial Average (DJIA) as an identity of a company, the relationship between business identity and CEO compensation is investigated. The results show that the CEO compensation of a company responds to the identity change while the compensation of an added company gradually increases toward the level of the DJIA companies starting before the year of addition, the compensation change of a replaced company is delayed until the replacement year and dropped quickly. This paper has some implications and contributes to recognizing and suggesting remedies on problems and biases in corporate governance.
\end{abstract}

Keywords: CEO Compensation, Identity, Peer group, Corporate Governance.

\section{INTRODUCTION}

In a paper on the public voice on CEO compensation (Song, Sohn, \& Herath, 2018), the business identity as a determinant of CEO compensation was proposed. The general business identity in collectivistic orientation rather than individual or relational orientation (Brickson, 2000 and 2007) such as Dow Jones 30 or S\&P 500 that is a malleable nominal attribute of a group of companies. General improvement of the performance of a company can lead to a new favorable identity for the company by adding to the Dow Jones Industrial Average (DJIA) index or S\&P 500 components, which in turn could improve the CEO compensation.

This paper investigates the proposition based on the Dow Jones Industrial Average (DJIA) components as the identity of the member companies. The DJIA is one of the most widely watched stock market indexes since its creation in 1896. When a company is replaced or added as one of the 30 DJIA components such as the recent replacement of General Electric by Walgreens Boots Alliance Inc. the identities of both companies change. As the identity of a company changes by either addition or replacement, the change of CEO compensation is examined.

From 1997 to 2013, there were eight changes in the DJIA components or 40 identity changes. Using the S\&P ExecuComp database and Research Insight, the association between CEO compensation and 
identity is investigated. The results show that the CEO compensation of a company after added to the DJIA component is higher than before addition to the DJIA; a similar result for the companies replaced by the DJIA component. Further, the results on the compensation adjustment processes in addition and replacement show biases in favor of higher CEO compensation.

The contributions of this paper are to establish the identity of a company as a determinant of CEO compensation and a better understanding of executive compensation adjustment processes. Since the identity such DJIA is decided externally by market likely competition, it can avoid many problems associated with the arbitrary selection of compensation peer group to determine a CEO compensation level. Considering the higher CEO compensation level (Mishel \& Schieder, 2016) and "pay without performance problem" of the US public companies (Bebchuk \& Fried, 2006), pay based on identity can be a very significant improvement of US corporate governance. Further, the insights gained from the adjustment processes of compensation of added and replaced companies provide useful insights to improve corporate governance related to the CEO compensation.

The next section presents research questions and data to analyze the impact of identity on CEO compensation followed by sections on analysis and data, results, and implications of the results. The final section addresses the conclusions of this study on corporate governance.

\section{RESEARCH QUESTION AND DATA}

Akerlof \& Kranton,(2000) defined identity as “a person's sense of self is associated with different social categories and how these categories should behave." Identity influences behavior and economic outcomes: payoffs of one's own actions and the payoffs of others' actions (Akerlof \& Kranton, 2000). In this paper, the general business identity in collectivistic orientation rather than individual or relational orientation (Brickson S. L., 2000 and 2007) is adopted. Note that our use of identity is different from other authors such as Fombrun (1996) who defined corporate identity as a "set of values and principles employees and managers associate with a company." For a general business identity which is a malleable nominal attribute of a group of companies can be a determinant of executive compensation of the companies. For a group of companies that their identities changed, the impact of the change to their total compensation of the CEO is investigated by comparing the CEO compensation of the added/replaced to unchanged companies as well as the compensation before and after of changed companies.

\section{ANALYSIS AND DATA}

From 1997 to 2013, there were eight changes in the DJIA components with 20 companies added to the DJIA component and the same number of replacements, which results in a total of 40 identity changes as a DJIA component company. For each of these identity change, the chief executive officer (CEO) compensation change in the after the identity change from the before was analyzed. Since the influence of identity on the CEO compensation can be cumulative over some years, single year compensations, as well as multiyear average compensation changes were considered. The single year compensation change is the change in the compensation in the first year after the identity change year (ICY) from the compensation in one year before the ICY. Multiple years such as two-year compensation change is the change in the two-year average compensation after the ICY from the two-year average before the ICY. The multiple year compensation changes are extended to a four-year average. The following equation defines the variables in detail:

$\mathrm{CC}_{\mathrm{i}}=\mathrm{CAF}_{\mathrm{i}}-\mathrm{CBF}_{\mathrm{i}}$

where $\mathrm{CC}$ is the compensation change of an added or a replaced company. The CAF and CBF are the average CEO compensation of the company after and before the ICY. The subscript $(i=1$ to 4$)$ indicates the number of years in calculating the average $\mathrm{CEO}$ compensation, for example, the subscript $\mathrm{i}=1$ is for 
one-year compensation after or before the ICY, and $\mathrm{i}=2$ is for 2-year average compensation. The compensation change included for one-year changes $\left(\mathrm{CC}_{1}\right)$ to multiyear changes $\left(\mathrm{CC}_{2}\right.$ to $\left.\mathrm{CC}_{4}\right)$.

The change in compensation after ICY from the compensation before the ICY $\left(\mathrm{CC}_{i}\right)$ may include the compensation change due to identity change and other variables such as compensation of peer group, and company-specific variables such as the size of the company. Namely, identity may not be the only determinant of CEO compensation. The CAF and/or CBF in Equation (1) needs to be adjusted by the other determinants. The change of the average of adjusted $\mathrm{CC}$ is hypothesized to equal to zero and tested for added companies and for replaced companies. To adjust the compensation change (CC), we assume that the CEO compensation as a function of peer group average compensation and various companyspecific variables,

$\mathrm{C}_{\mathrm{i}, \mathrm{t}}=\mathrm{f}\left(\mathrm{CA}_{\mathrm{t}}, \mathrm{S1}_{\mathrm{i}, \mathrm{t}} \ldots \mathrm{Sn}_{\mathrm{I}, \mathrm{t}}\right)$

where, $\mathrm{C}_{\mathrm{i}, \mathrm{t}}$ is $\mathrm{CEO}$ compensation of company $\mathrm{i}$ at year $\mathrm{t}, \mathrm{CA}_{\mathrm{t}}$, is average compensation of the company i's peer group at year $\mathrm{t}$, and $\mathrm{S} 1_{\mathrm{i}, \mathrm{t}}$ to $\mathrm{Sn}_{\mathrm{i}, \mathrm{t}}$ are company i specific variables, such as sales volume as a proxy of company size. To operationalize the equation 2.1 , the following a multiplicative model (2.2) is used.

$\ln \left(\mathrm{C}_{\mathrm{i}, \mathrm{t}}\right)=\alpha_{0 . \mathrm{i}}+\alpha_{1} \ln \left(\mathrm{CA}_{\mathrm{t}}\right)+\beta_{1} \ln \left(\mathrm{S} 1_{\mathrm{i}, \mathrm{t}}\right)+\ldots+\beta_{\mathrm{n}} \ln \left(\mathrm{Sn}_{\mathrm{i}, \mathrm{t}}\right)$

Note that in equation (2.2), only $\alpha_{0 . \mathrm{i}}$ is ith company-specific value and all others including $\alpha_{1}$ and $\beta_{1}$ to $\beta_{\mathrm{n}}$ are identity or group specific values. Equation (2.2) is estimated and used to adjust $\mathrm{CAF}_{\mathrm{i}}$ or $\mathrm{CBF}_{\mathrm{i}}$ in equation (1) to estimate the net identity impact to the CEO compensation. Estimating and adjusting compensations before the ICY for a replaced company or after the ICY for added companies are explained in Appendix 1.

To analyze the impact of identity, two sets of data are used: the CEO compensation data and company-specific data. The S\&P's ExecuComp database for the CEO compensation data and the S\&P's Research Insight for company-specific data are used. The ExecuComp database contains two total compensation measures: TDC1 and TDC2. The TDC1 is defined as the total direct compensation that includes salary, bonus, other annual compensation, restricted stock grants, long-term incentive payouts, the total value of stock options granted using the Black-Scholes, and other compensation. TDC2 is total direct compensation that includes salary, bonus, other annual compensation, restricted stock grants, longterm incentive payouts, the value of stock options exercised, and other compensation. The difference between TDC1 and TDC2 is in the valuing stock options. While the TDC1 includes the total value of the stock options granted, the TDC2 is based on the value of options exercised. The TDC1 is used in this study to measure the CEO compensation of a company since the TDC1 is more suitable as the company is the financier of CEO compensation, and the purpose of this study is to investigate the impact of identity to the CEO compensation decision.

\section{RESULTS}

The results of the analysis are summarized in the following tables. Table 1 shows that the average total direct compensation of the CEO of a company increases as the company is added to the DJIA index component or decreases as the company is replaced. For both added and replaced companies, the amounts of change are statistically significant except the change in the first year after the ICY from the one year before ICY of the added companies. The identity of a company as a DJIA Index component is associated with CEO compensation. The Change in \% column of Table 1 shows the percentage change of compensation from the before ICY to the after ICY in terms of compensation as a DJIA component for both added and replaced companies, For the added companies, the increments of compensation changes were gradual: the increase of compensation in one-year-after from the one-year-before the ICY was $14.3 \%$, and gradually moved up to $28.8 \%$ for the four-year average before to four-year average after the ICY. In the cases of replacing companies, the change in compensation was a quick drop by $48.6 \%$ in the 
first year and maintained at about $48 \%$ level in the second to fourth year. In both cases, as a company was added to or replaced from the DJIA components, the average responses of CEO compensation in increasing or decreasing are statistically significant. In Figure 1, year 0 is the identity change year and the average compensation of added (AvTDCa) and replaced companies (AvTDCr) are in $\$ 1000$. Figure 1 clearly shows the different patterns of change between added companies and replaced companies in their average compensation during the 4-year before the change to 4-year after the change.

TABLE 1

AVERAGE CHANGE IN CEO COMPENSATION AFTER IDENTITY CHANGE

\begin{tabular}{|c|c|c|c|c|}
\hline & No of Years & $\begin{array}{c}\text { Change in } \\
\$ \mathrm{~m}\end{array}$ & t-ratio & Change in \% \\
\hline \multirow{3}{*}{ Added Cos } & 1 & 1.9 & 0.95 & 14.3 \\
\cline { 2 - 5 } & 2 & 3.4 & $1.88^{*}$ & 21.9 \\
\cline { 2 - 5 } & 3 & 4.2 & $1.84^{*}$ & 26.7 \\
\cline { 2 - 5 } & 4 & 4.5 & $1.92^{*}$ & 28.8 \\
\hline Replaced Cos & 1 & -12.07 & $-2.21^{* *}$ & -58.6 \\
\cline { 2 - 5 } & 2 & -10.82 & $-2.14^{*}$ & -50.6 \\
\cline { 2 - 5 } & 3 & -10.28 & $-2.06^{*}$ & -47.9 \\
\cline { 2 - 5 } & 4 & -9.43 & $-2.20^{* *}$ & -46.1 \\
\hline
\end{tabular}

${ }^{*} \mathrm{p}<0.1,{ }^{* *} \mathrm{p}<0.05,{ }^{* * *} \mathrm{p}<0.01 \mathrm{H}_{1}: \mu \neq 0$ for added and $\mathrm{H}_{1}: \mu \neq 0$ for replaced companies. Change in $\%$ in terms of the compensation as DJIA component for added and replaced companies.

FIGURE 1

AVERAGE COMPENSATION OF ADDED (AVTDCA) AND REPLACED (AVTDCR)

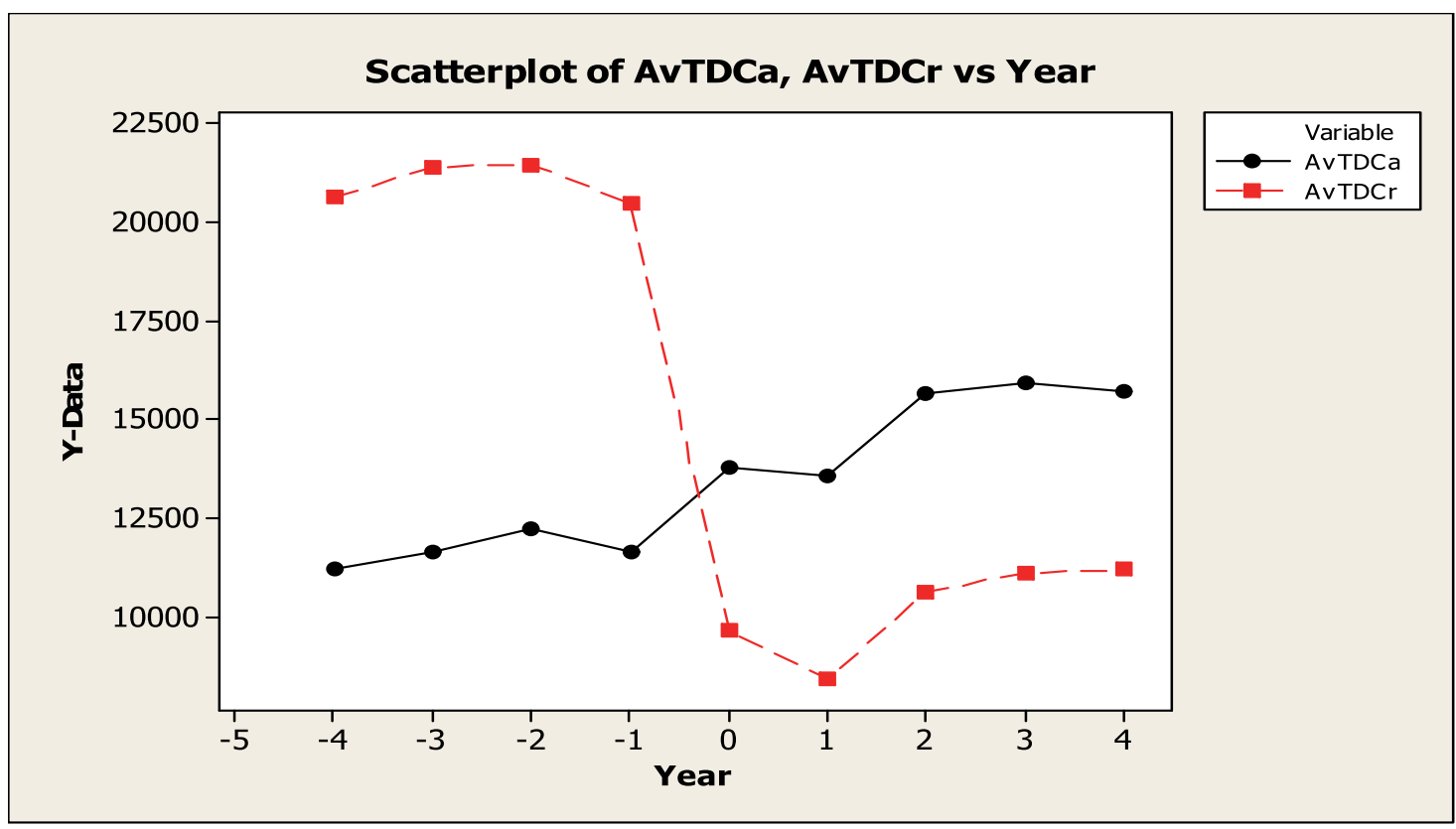

Table 2 shows the differences of the CEO compensation of added or replaced companies as the components of the DJIA index to the compensation of the stayed companies. When a company added to the DJIA index, the CEO compensation increased to a level that is $\$ 2.98$ million lower than the average compensation of the companies stayed in the DJIA Index. For the replaced companies, their annual 
compensation as component companies in DJIA is $\$ 0.37$ million less than the staying companies. Further, the p-values indicate that the average compensation of added companies is significantly different from the stayed companies, the average of the replaced companies is not significantly different from the average compensation of stayed companies.

TABLE 2 COMPARISON OF CHANGED TO STAYED COMPANIES IN COMPENSATION

\begin{tabular}{|c|c|c|c|c|}
\hline & \multicolumn{4}{|c|}{ Changed - Stayed Companies' Compensation } \\
\cline { 2 - 5 } & Mean diff. & t-ratio of mean diff. (p-value*) & Mean & Changed/Stayed \\
\hline Added Cos & $\$-2.98 \mathrm{~m}$ & $-1.85(0.085)$ & $\$ 16.0$ & $89 \%$ \\
\hline Replaced Cos & $\$-0.37 \mathrm{~m}$ & $-0.20(0.85)$ & $\$ 15.2$ & $95 \%$ \\
\hline
\end{tabular}

* p-value for the Test of $\mu=0$ vs $\neq 0$.

By combining the results of both Table 1, Figure 1 and Table 2 indicate that CEO compensation is influenced by the change of identity. The CEO compensation of the added companies gradually increases toward the level of compensation of stayed companies starting well before the identity change year, and the changes for replaced companies happen after the ICY.

In summary, the results show that the company identity as one of the DJIA components and the CEO compensation are associated with each other as proposed. Further, the CEO compensation adjustment processes of the companies that were added and replaced are different. For the added companies, their average CEO compensation gradually increases toward the level of the average of the DJIA companies over a few years before the addition. For the replaced companies, their adjustments were delayed until a replacement from the DJIA; their CEO compensation average drop by a $60 \%$ level in the first year after the replacement.

The association between identity and CEO compensation indicates that the use of the business identity as a base of benchmarking of the CEO compensation level, and dis-symmetric adjustment processes between companies added to and replaced from DJIAompanies suggest myopia on added and replaced companies. These will be further discussed and their implications on corporate governance are addressed in the following section.

\section{IMPLICATIONS OF THE RESULTS}

As various authors in the literature (Holmstrom \& Kaplan, 2003; Cadman \& Carter, 2014; Merlin \& Diamond, 2015) reported, the benchmarking CEO compensation level to compensation peer group has been widely practiced. The responses of the merits of benchmarking are mixed depending on how a compensation peer group is defined. Merlin \& Diamond ( 2015) reports that it is not an uncommon practice to pick peers that are larger than themselves, big jumps in pay sometimes follow. Examples are Jarden picking Oracles Corp., and Johnson \& Johnson as the peer for almost half of S\&P 100 companies (Merlin \& Diamond, 2015). The Conference Board recommendations that are introduced in Holmstrom \& Kaplan (2003) paper include "the compensation committee should be independent and should avoid benchmarking."

On the contrary, however, Holmstrom \& Kaplan (2003) proposed "more effective benchmarking, not less" to set executive compensation levels. The identity such the DJIA is determined independently from the compensation committee or CEOs by external market-like competition. Thus identity is more an appropriate determinant of the CEO compensation than the compensation peer group determined by the company.

As the change of company identity by adding to or replacing from the DJIA component is associated with the CEO compensation changes, the processes of adjustment by added and replaced companies are dis-symmetric and different. Added companies and replaced companies show different adjustment patterns in their average CEO compensation. Namely, the CEO compensation of the added companies 
gradually moves toward the average of DJIA companies before the identity change year (ICY), but the average compensation of the replaced was at the level of the remaining DJIA companies' until the ICY and significantly and quickly dropped after they were replaced from the DJIA components. This seemingly dis-symmetry in compensation adjustments between added and replaced companies indicates that the compensation increases and decreases are differently recognized and enacted: the general improvement of the performance of a company that leads to an addition to the DJIA is closely recognized and rewarded by increasing CEO compensation well before the actual addition of the company to the DJIA components, but the general deterioration of performance leading to the replacement of a company from the DJIA components and the compensation reductions of the companies are delayed until their replacements from the DJIA. The delay of compensation deductions indicates that the unfavorable situation is recognized only with a clear result, i.e, a replacement from the DJIA index components. There is a built-in bias against recognizing the failure and reducing the compensation of the CEO. The built-in bias in favor of early recognition and increase of compensation for an added company or delaying the reduction of compensation until the identity change year can lead to a higher payout in an identity change than in no change. Thus the bias can lead to higher compensation and further it supports the lack of independence of the board of directors which is a base of criticism on the compensation peer group.

The built-in bias is proposed as the myopia of overlooking failures by Levinthal \& March (1993), which indicates the CEO's influence to the board compensation committee (Bebchuk \& Fried, 2006) and/or the conflicts of interest of the board. To counter the bias or myopia, the corporate governance needs to be improved by enhancing the independence of the board and separating the board functions of selection/hiring CEO from the compensation to reduce the conflicts of interest. The practice of compensation peer group benchmarking, executive power on the board, and the built-in bias of board all indicate and explain the upward pressure of CEO compensation.

\section{CONCLUSIONS}

The investigation of the CEO compensation change of the companies added to and replaced from the DJIA Index components indicates an association of the CEO compensation of a company with the identity as a DJIA component and the dis-symmetric processes of change of compensation between companies added to and replaced from the DJIA component.

The identity such as DJIA is useful in providing compensation level to the board to determine the CEO compensation more appropriately than the widely practiced compensation peer group on benchmarking. The lack of independence of the current practice of benchmarking executive compensation based on the compensation peer group should be improved by introducing market mechanism such as business identity.

The application of identity such as DJIA is limited only for the companies in DJIA components. Thus, the business identity to be an effective mechanism for executive compensation determination, it is necessary to develop the clusters of identity applicable to all companies, such as industrial classification. Developing the clusters of identity pre-requires a comprehensive study on the determinants of CEO compensation including and not limited to the long-term performance, the complexity of the business, the essentiality of CEO to employees (Aoki, 2010). It is an important extension of our study and promises a significant contribution to corporate governance in general.

The dis-symmetric responses in the CEO compensation to the change in identity by adding or replacing can be an indication of built-in bias in overlooking the failures leading to a replacement and focusing on the successes for addition. The built-in bias needs to be recognized in corporate governance by establishing procedures for failures as well as successes. 


\section{REFERENCES}

Akerlof, G. A., \& Kranton, R. E. (2000). Economics of Identity. Quarterly Journal of Economics, 115(3), 715-753.

Aoki, M. (2010). Corporations in Evolving Diversity: Cognition, Governance, and Institutions. New York: Oxford University Press.

Bebchuk, L. A., \& Fried, J. M. (2006). Pay without Performance: Overview of the Issue. Academy of Management Perspectives, 5-24, February

Brickson, S. L. (2000). The Impact of Identity Orientation on Individual and Organizational Outcomes in Demographically Diverse Settings. Academy of Management Review, 25(1), 82-101.

Brickson, S. L. (2007). Organizational Identity Orientation: The genesis of the role of the firm and distinct forms of social value. Academy of Management Review, 32(3), 864-888.

Cadman, B., \& Carter, M. E. (2014). Compensation Peer Groups and Their Relation with CEO Pay. Journal of Management Accounting Research, 26(1), 57-82.

Fombrun, C. J. (1996). Reputation: Realizing Value from the Corporate Image. Boston: Harvard Business School Press.

Holmstrom, B., \& Kaplan, S. A. (2003, Spring). The State of U.S. Corporate Governance: What'd Right and What'd Wrong? Journal of Applied Corporate Finance, 15(3), 8-20.

Levinthal, D. A., \& March, J. G. (1993). The Myopia of Learning. Strategic Management Journal, 14(Winter), 95-112.

Merlin, A., \& Diamond, J. S. (2015). How Companies Justify Big Pay Raises for CEOs. Bloomberg . Retrieved June 4, from https://www.bloomberg.com/graphics/2015-executive-pay-peer-groups/

Mishel, L., \& Schieder, J. (2016). Stock market headwinds meant less generous year for some CEOs. Washington, DC: Economic Policy Institute.

Song, J. H., Sohn, C., \& Herath, S. (2018). Firms responding to the voice on CEO compensation. Journal of Applied Business and Economics, 20(4).

Steinberg, R. M. (2011). Governance, Risk Management, and Compliance. Hoboken, New Jersey: John Wiley \& Sons, Inc.

Subramanian, G. (2015, March). Corporate Governance 2.0. Harvard Business Review, 93(3), 96-105.

Williamson, O. E. (2005, May). The economics of governance. American Economic Review, 95(2), 1-18. 


\section{APPENDIX}

\section{ADJUSTMENT TO ESTIMATE CEO COMPENSATIONS}

To estimate the impact of identity change, the CEO compensation of company $i$ at year $t\left(C_{i, t}\right)$ in equation (2.2) is estimated using the data of the companies that were stayed as the DJIA components during the period from 1997 to 2013; there were 15 companies.

$\ln \left(\mathrm{C}_{\mathrm{i}, \mathrm{t}}\right)=\alpha_{0 . \mathrm{i}}+\alpha_{1} \ln \left(\mathrm{CA}_{\mathrm{t}}\right)+\beta_{1} \ln \left(\mathrm{S}_{\mathrm{i}, \mathrm{t}}\right)+\ldots+\beta_{\mathrm{n}} \ln \left(\mathrm{Sn}_{\mathrm{i}, \mathrm{t}}\right)$

where, $\mathrm{CA}_{\mathrm{t}}$ is average compensation of the 15 stayed companies at year $\mathrm{t}(\mathrm{AC})$, and $\mathrm{S1}_{\mathrm{i}, \mathrm{t}}$ to $\mathrm{Sn}_{\mathrm{i}, \mathrm{t}}$ are company i's specific variables. For the company-specific variables, the number of employees (E), sales volume (S), and the return of equity (ROE) are used. Note that in equation (2.2), only $\alpha_{0 . \mathrm{i}}$ is ith company-specific value estimated by using indicator variables, and all others including $\alpha_{1}$ and $\beta_{1}$ to $\beta_{\mathrm{n}}$ are identity or group specific values. The results of regression models are summarized in Table a.1 below.

TABLE A.1

\section{SUMMARY OF REGRESSION ESTIMATION}

\begin{tabular}{|c|c|c|c|c|c|c|c|c|}
\hline Model no & \multicolumn{2}{|c|}{$\mathrm{R}^{2} / \mathrm{Adj} \mathrm{R}^{2}(\%)$} & $\alpha_{0 . \mathrm{i}}$ for each co. & one $\alpha_{0 . \mathrm{i}}$ for all co. & CA & E & S & ROE \\
\hline 1 & 50.1 & 47.4 & $\checkmark$ & & $\checkmark$ & $\checkmark$ & $\checkmark$ & $\checkmark$ \\
\hline 2 & 49.7 & 47.2 & $\checkmark$ & & $\checkmark$ & & $\checkmark$ & $\checkmark$ \\
\hline $3 *$ & 49.5 & 47.0 & $\checkmark$ & & $\checkmark$ & $\checkmark$ & $\checkmark$ & \\
\hline 4 & 48.1 & 45.7 & $\checkmark$ & & $\checkmark$ & & $\checkmark$ & \\
\hline 5 & 45.3 & 42.9 & $\checkmark$ & & $\checkmark$ & & & \\
\hline 6 & 16.5 & 13.1 & $\checkmark$ & & & & & \\
\hline 7 & 36.2 & 35.7 & & $\checkmark$ & $\checkmark$ & $\checkmark$ & $\checkmark$ & $\checkmark$ \\
\hline 8 & 34.7 & 34.9 & & $\checkmark$ & $\checkmark$ & & $\checkmark$ & $\checkmark$ \\
\hline
\end{tabular}

$\checkmark$ indicates the variable is included in the model and blank cell indicates not included

The Model 3 is selected and used to adjust CEO compensation in equation (1) to estimate the identity impact to the CEO compensation; to avoid the problem with a negative value of ROE, Model 1 and 2 are not used although their $\mathrm{R}^{2}$ are slightly higher than Model 3.

The next step is to use the Model 3 and adjust compensation when a company was a component of the DJIA for each of both the added and replaced companies. For an added company i, the determinants of compensation at time $\mathrm{t}+$ and $\mathrm{t}-$ are $\left(\mathrm{CA}_{\mathrm{t}^{+}}, \mathrm{E}_{\mathrm{t}^{+}}, \mathrm{S}_{\mathrm{t}^{+}}\right)$and $\left(\mathrm{CA}_{\mathrm{t}-}, \mathrm{E}_{\mathrm{t}-}, \mathrm{S}_{\mathrm{t}-}\right)$. Using the Model 3 the corresponding compensations, $\mathrm{C}_{\mathrm{t}+}, \mathrm{C}_{\mathrm{t}-}$ are:

$\ln \left(\mathrm{C}_{\mathrm{i}, \mathrm{t}^{+}}\right)=\mathrm{a}_{0 . \mathrm{i}}+\mathrm{a}_{1} \ln \left(\mathrm{CA}_{\mathrm{t}+}\right)+\mathrm{b}_{1} \ln \left(\mathrm{E}_{\mathrm{i}, \mathrm{t}^{+}}\right)+\mathrm{b}_{2} \ln \left(\mathrm{S}_{\mathrm{i}, \mathrm{t}^{+}}\right)$

$\ln \left(\mathrm{C}_{\mathrm{i}, \mathrm{t}-}\right)=\mathrm{a}_{0 . \mathrm{i}}+\mathrm{a}_{1} \ln \left(\mathrm{CA}_{\mathrm{t}-}\right)+\mathrm{b}_{1} \ln \left(\mathrm{S}_{\mathrm{i}, \mathrm{t}-}\right)+\mathrm{b}_{2} \ln \left(\mathrm{S}_{\mathrm{i}, \mathrm{t}-}\right)$

In the equations (a.1) and (a.2), the coefficients $a_{1}, b_{1}$ and $b_{2}$ are the regression estimates of $\alpha_{1}, \beta_{1}$, and $\beta_{2}$ of equation (2.2). Also the equation (a.1) and (a.2) include two unknown factors/variables, namely, $\mathrm{a}_{0 . \mathrm{i}}$ and $\mathrm{C}_{\mathrm{i}, \mathrm{t}-\mathrm{f}}$ From the equation (a.1) and (a.2), the adjusted compensation $\left(\mathrm{C}_{\mathrm{i}, \mathrm{t}-}\right)$ is determined and used to estimate the identity impact on CEO compensation. For the replaced companies, their compensations are adjusted by a similar procedure. 
The average compensations of added and replaced are $89 \%$ and $95 \%$ of stayed companies' average compensation, respectively as shown in Table a. 2 below. These values are used in the equation (a.1) and (a.2) for CA for added or replaced companies' average.

\section{COMPARISON OF CHANGED TO STAYED COMPANIES IN COMPENSATION}

\begin{tabular}{|c|c|c|c|c|}
\hline & \multicolumn{4}{|c|}{ Changed - Stayed Companies' Compensation } \\
\hline & Mean diff. & t-ratio of mean diff. (p-value*) & Mean & Changed/Stayed \\
\hline Added Cos & $\$-2.98 \mathrm{~m}$ & $-1.85(0.085)$ & $\$ 16.0$ & $89 \%$ \\
\hline Replaced Cos & $\$-0.37 \mathrm{~m}$ & $-0.20\left(0.85^{*}\right)$ & $\$ 15.2$ & $95 \%$ \\
\hline
\end{tabular}

${ }^{*}$ p-value for the Test of $\mu=0$ vs $\neq 0$.

The following two tables show average changes in CEO compensation after identity change based on adjusted compensation (Table a.3) and based on un-adjusted compensation (Table a.4). Comparing results in Table a.3 and Table a.4, adjustment of compensation does not make any difference in terms of conclusions.

TABLE A.3

ADJUSTED AVERAGE CHANGE IN CEO COMPENSATION AFTER IDENTITY CHANGE

\begin{tabular}{|c|c|c|c|c|}
\hline & No of Years & Change in $\$ \mathrm{~m}$ & t-ratio & Change in \% \\
\hline \multirow{3}{*}{ Added Cos } & 1 & 1.9 & 0.95 & 14.3 \\
\cline { 2 - 5 } & 2 & 3.4 & $1.88^{*}$ & 21.9 \\
\cline { 2 - 5 } & 3 & 4.2 & $1.84^{*}$ & 26.7 \\
\cline { 2 - 5 } & 4 & 4.5 & $1.92^{*}$ & 28.8 \\
\hline \multirow{3}{*}{ Replaced Cos } & 1 & -12.07 & $-2.21^{* *}$ & -58.6 \\
\cline { 2 - 5 } & 2 & -10.82 & $-2.14^{*}$ & -50.6 \\
\cline { 2 - 5 } & 3 & -10.28 & $-2.06^{*}$ & -47.9 \\
\cline { 2 - 5 } & 4 & -9.43 & $-2.20^{* *}$ & -46.1 \\
\hline
\end{tabular}

${ }^{*} \mathrm{p}<0.1, * * \mathrm{p}<0.05, * * * \mathrm{p}<0.01 \mathrm{H}_{1}: \mu \neq 0$ for added and $\mathrm{H}_{1}: \mu \neq 0$ for replaced companies. Change in $\%$ in terms of the compensation as DJIA component for added and replaced companies.

TABLE A.4

\section{UN-ADJUSTED AVERAGE CHANGE IN CEO COMPENSATION AFTER IDENTITY CHANGE}

\begin{tabular}{|c|c|c|c|c|}
\hline & No of Years & Change in $\$ \mathrm{~m}$ & t-ratio & Change in \% \\
\hline \multirow{3}{*}{ Added Cos } & 1 & 1.4 & 1.48 & 0.10 \\
\cline { 2 - 5 } & 2 & 4.6 & $2.20^{*}$ & 0.27 \\
\cline { 2 - 5 } & 3 & 5.9 & $2.52^{*}$ & 0.33 \\
\cline { 2 - 5 } & 4 & 6.6 & $2.73^{*}$ & 0.36 \\
\hline \multirow{3}{*}{ Replaced Cos } & 1 & -6.3 & $-1.86^{*}$ & -0.43 \\
\cline { 2 - 5 } & 2 & -5.1 & $-2.18^{* *}$ & -0.32 \\
\cline { 2 - 5 } & 3 & -4.8 & $-2.01^{*}$ & -0.32 \\
\cline { 2 - 5 } & 4 & -4.3 & $-2.05^{*}$ & -0.30 \\
\hline
\end{tabular}

${ }^{*} \mathrm{p}<0.1,{ }^{* *} \mathrm{P}<0.05,{ }^{* * *} \mathrm{p}<0.01 \mathrm{H}_{1}: \mu>0$ for added and $\mathrm{H}_{1}: \mu \neq 0$ for replaced companies. Change in $\%$ in terms of the compensation as DJIA component for added and replaced companies. 